ENHANCING OF TEACHERS' PROFESSIONAL COMPETENCE LEVEL IN THE USEAGE OF FOLK TOYS IN THE CORRECTIONAL AND EDUCATIONAL PROCESS OF PRIMARY SCHOOL AGE CHILDREN WITH REDUCED VISION

\title{
ПІДВИЩЕННЯ РІВНЯ ФАХОВОЇ КОМПЕТЕНТНОСТІ ПЕДАГОГІВ У ВИКОРИСТАННІ НАРОДНОЇ ІГРАШКИ В КОРЕКЦІЙНО-ОСВІТНЬОМУ ПРОЦЕСІ ДІТЕЙ МОЛОДШОГО ШКІЛЬНОГО ВІКУ ЗІ ЗНИЖЕНИМ ЗОРОМ
}

\author{
ALICE DASHKOVSKA, \\ Graduate student \\ АЛІСА ДАШКОВСЬКА, \\ аспірант \\ https://orcid.org 0000-0001-8745-4280 \\ 3802417@ukr.net \\ National Pedagogical Dragomanov \\ University \\ Національний педагогічний \\ університет імені \\ М.П.Драгоманова \\ $\triangle 9$ Pirogova St., \\ $\triangle$ вул. Пирогова, 9, \\ Kyiv, 01601 \\ м. Київ, 01601 \\ Original manuscript received July 07, 2019 \\ Revised manuscript accepted September 09, 2019
}

\begin{abstract}
The article notes that remedial and compensatory focus of the teaching and education of children with visual impairments is the content of all educational activities in the institutions with special education that is implemented during the formation of competences necessary for their further socialization. An important value is acquired by the use of folk toy becomes more important in correctional and educational work of Ukrainian special education institutions for primary school age children with visual impairments, which helps to eliminate secondary deviation, resulting from the impairment.

It is noted that the low level of primary school age pupils' activity with visual impairments with a folk toy by the fact that it did not find its proper place in the educational process of special schools and is characterized by a number of reasons, the main of which is the ignorance of teachers about the possibilities of using folk toys in correctional-educational process.

An experimental methodology for increasing teachers' professional competence level to use Ukrainian folk toys in the correctional and educational process in educational institutions for children with low vision is offered.

The experimental method was realized in three stages. At the first stage teachers got acquainted theoretically with Ukrainian folk toy as a type of arts and crafts on the seminars. There were the conducted training on the second stage on which teachers were acquainted with prerequisites of development of creative activities and


technology of artistic and pedagogical activities. The third stage of enhancing the professional competence of teachers was devoted to a series of workshops on making traditional Ukrainian folk toys.

The proposed experimental methodology included which included seminars, workshops and training sessions helped to increase the professional competence of teachers to use Ukrainian folk toys in work with children with low vision.

Key words: methodology, folk toy, competence, correction-educational process, low vision.

Вступ. Одним із головних напрямків системи спеціальної освіти $€$ корекційна робота з дітьми, які мають з порушення психофізичного розвитку.

Корекційно-компенсаторна спрямованість навчання й виховання дітей з порушеннями зору є змістом усієї освітньої діяльності закладу спеціальної освіти, що реалізується під час фрормування компетентностей, потрібних для подальшої їх соціалізації.

Аналіз сучасної спеціальної психолого-педагогічної літератури показав, що найефективніший корекційно-компенсатний вплив у освітньому процесі дітей зі зниженим зором досягається шляхом залучення іï до активної й цілеспрямованої предметно-практичної діяльності (Андрієнко, 1994, Моргуліс, 1984, Синьова, 2012, Федоренко, 2016 та ін.). Разом з тим, в ряді тифлологічних дослідженнях (Земцова, 1973, Синьова, 2016, Федоренко, 2016 та ін.) відмічається, що порушення зору впливає на розвиток рухів дитини та ії просторове орієнтування, тобто на найбільш суттєві елементи предметної діяльності. Таким чином, труднощі формування предметно-практичної діяльності в дітей зі зниженим зором визначається дослідниками як вторинне відхилення у їхньому розвитку (Литвак, 2006, Моргуліс, 1984, Синьова, 2012 та ін.).

Враховуючи, що предметно-практична діяльність $€$ основним засобом розвитку чуттєвого сприймання та компенсації зорової недостатності, а також основою реалізації різних напрямків виховання (естетичного, морального, розумового, патріотичного та ін.), важливого значення набуває використання в корекційно-виховній роботі закладів спеціальної освіти для дітей зі зниженим зором української народної іграшки, діяльність з якою сприяє усуненню вторинних відхилень, що виникли внаслідок порушення зору.

Успішність оволодіння предметно-практичною діяльністю залежить від наявності в дітей інтересу до об'єктів та умов розвитку сенсорних дій, що включають виконання практичних завдань поряд з інтелектуальними за чітко визначеними етапами педагогічного керівництва (Моргуліс, 1984, Свиридюк, 1981, Синьова, 2012, Федоренко, 2016 та ін.), робота 3 виготовлення народної іграшки може стати для учнів зі зниженим зором ефективним засобом корекції пізнавальної, ігрової та трудової діяльності.

Проведене дослідження показало, що низький рівень діяльності учнів молодшого шкільного віку 3 зоровою депривацією 3 народною іграшкою пояснюється тим, що вона не знайшла свого належного місця в освітньому процесі та характеризується цілим рядом причин: чинні навчальні програми не передбачають ознайомлення учнів початкових 
класів з народною іграшкою; педагоги не знайомі з нею та методикою застосування в корекційно-виховній роботі з дітьми, які мають знижений зір; значна частина тифлопедагогів не знають, що народну іграшку можна використати як дієвий засіб не лише морального, трудового, національного, патріотичного, естетичного виховання, а також як корекційний засіб (Дашковська, 2018).

На нашу думку, ефективне застосування українських народних іграшок в учнів початкових класів зі зниженим зором багато в чому залежить від цілеспрямованого педагогічного керівництва цим процесом. 3 цією метою нами було розроблену експериментальну методику підвищення рівня фахової компетентності педагогів щодо використання української народної іграшки в корекційно-виховному процесі освітніх закладів для дітей молодшого шкільного віку зі зниженим зором.

Методи та методики дослідження. У дослідженні було використано такі методи: аналіз, синтез, систематизація, порівняння інформації у філософській, спеціальній психолого-педагогічній літературі 3 проблеми дослідження 3 метою визначення його теоретикометодологічних засад; а також формувальний експеримент, який передбачав розробку семінарів, майстер-класів, тренінгів, технологій різних видів, метод конкретних ситуацій і був спрямований на вдосконалення методики використання української народної іграшки в корекційно-виховному процесі шкіл для дітей зі зниженим зором.

Результати дискусії. При розробці експериментальної методики ми спирались на методологічні засади фрілософії, що забезпечуються філософсько-аксіологічним та філософсько-онтологічним підходами (Виготський, 1995, Синьов, 2010, Тарасун, 2004). Згідно з філософськоаксіологічним підходом розв'язання корекційних завдань вимагає від педагога особистої відповідальності за результат корекційної роботи, належного рівня толерантності, професійної майстерності, ставлення до дитини зі зниженим зором як до цілісної особистості з вірою у її потенційні можливості розвитку.

Для підвищення рівня фахової компетентності вчителів початкових класів, вихователів тощо про українську народну іграшку нами були обрані семінари, майстер-класи та тренінги. Ці форми роботи сьогодні активно впроваджується для швидкої адаптації педагогів до реформ у галузі освіти, зокрема підготовки вчителів до впровадження нового Державного стандарту початкової освіти в науково-методичних центрах та закладах освіти.

Робота у цьому напрямку була спрямована на:

- отримання педагогами на семінарах достатнього обсягу систематизованої інформації про народну іграшку: історії виникнення, види, значення та розповсюдження різних її видів на території України;

- ознайомлення педагогів на тренінгах 3 новими педагогічними технологіями корекційно-виховної роботи на уроках та позаурочний час;

- ознайомлення педагогів на майстер-класах 3 різними технологіями виготовлення українських народних іграшок; 
- стимулювання педагогів до саморозвитку і самовдосконалення.

Підвищення фахової компетентності відбувалось поетапно.

На I етапі педагоги на семінарах теоретично ознайомлювались 3 українською народною іграшкою як видом декоративно-прикладного мистецтва. 3 цією метою протягом двох семінарів педагоги готували виступи і презентації на теми, що стосуються фрормування знань про українську народну іграшку.

У результаті відвіданих семінарів педагоги отримали знання про українську народну іграшку - ії̈ види, історичний шлях розвитку та вплив на виховання дітей.

На II етапі з підвищення фахової компетентності педагогів були проведені тренінги, на яких педагогів знайомили 3 передумовами розвитку творчої діяльності та технологіями художньо-педагогічної діяльності: інтегративними, проблемно-евристичними, ігровими, музейними, проектними технологіями, оцінювання образотворчої діяльності учнів в контексті компетентнісного підходу.

Кожен тренінг будувався за такою структурою:

1. Міні-лекція, на якій розглядались основні технології навчання. Інформація подавалась структуровано та систематизовано протягом 1015 хвилин, для підвищення зацікавленості та мотивації учасників тренінгу міні-лекція супроводжувалась презентацією 3 демонстрацією наочних прикладів практичних завдань.

2. Групова дискусія, на якій проводилось обговорення після отриманої теоретичної інформації. Педагоги висловлювали свої думки, позиції, враження щодо доцільності використання певної технології 3 дітьми, враховуючи їх вік, особливості зорового сприймання та досвіду практичної діяльності.

3. Метод конкретних ситуацій (кейсів). Педагоги отримували завдання розробити алгоритм запитань та практичні вправ з навчальної теми для реалізації визначеної педагогічної технології. Після цього проводилась презентація або рольова гра для демонстрації розроблених завдань педагогічної технології.

4. Рефлексія застосовувалась як для оцінки побудови тренінгу i його подальшого удосконалення, так і для самооцінювання педагогів, коли вони визначали труднощі, з якими зіштовхнулися, визначали свої досягнення та подальші перспективи використання даної технології у своїй роботі.

Першим проводився тренінг “Передумови розвитку творчої діяльності", на якому педагоги ознайомлювалися 3 технологіями корекційно-виховної роботи. На тренінговому занятті розглядалось сприймання як один з основних компонентів творчої діяльності, а також питання формування предметно-практичної діяльності у дітей 3 порушеннями зору та основні методи сенсорного виховання та особливості їх використання 3 даною нозологією при різній зоровій патології (Гребенюк, 2005, Сасіна, 2005, Тімакова, 2005). Особлива увага 
була приділена оволодінню прийомами дотикового обстеження предметів учнями, а також розвитку їх дотикової чутливості.

Під час роботи над кейсами педагоги працювали над розробкою:

- алгоритму обстеження української народної іграшки; технологічних карток виготовлення українських народних іграшок, які б враховували особливості зорового сприймання учнів;

- -комплексу вправ для розслаблення кистей рук.

На двох наступних тренінгах розглядались технології художньопедагогічної діяльності, які описані в роботах Масол, 2015.

Під час групової дискусії було прийняте рішення на методичному об'єднанні вчителів початкових класів узгодити календарно-тематичне планування уроків трудового навчання (2-4 класи), "Я досліджую світ. Технології" (1 клас) та уроків образотворчого мистецтва у змістовій лінії “Декоративно-ужиткове мистецтво" на новий навчальний рік. Вихователям груп розробити планування виховної роботи, орієнтуючись на тематичне потижневе планування роботи вчителів початкових класів та вихователів груп 1 класу Нової української школи, з подальшим обговоренням на методичному об'єднанні.

Робота над удосконаленням календарно-тематичного планування сприяла кількісному збільшенню об’єктів вивчення, а також узагальненості, конкретизації уявлень учнів про українську народну іграшку.

Під час роботи над кейсами реалізації педагогами інтегративних художньо-педагогічних технологій з метою формування образотворчої компетентності про українські народні іграшки у учнів зі зниженим зором були запропоновані такі практичні завдання:

1. Визначити настрій народної музичної композиції та підібрати ляльку-мотанку, яка б могла бути головною героїнею музичного твору. орнаментах.

2. Відобразити почуті музичні ритми в українських народних

3. Створити композицію до народної казки, виготовивши героїв 3 глини.

4. Порівняти ляльки-мотанки.

5. Підібрати прислів'я, якими можна охарактеризувати виготовлену українську народну іграшку.

Особливий акцент під час тренінгів був зроблений на ігрові технології. Під час групової дискусії педагоги визначили важливість використання ігрових технологій у різних видах діяльності учнів зі зниженим зором початкових класів, що сприятиме формуванню міжособистісних стосунків, навичок невербального спілкування, розвитку слухового сприймання, формуванню основних рухів і рухових якостей, орієнтуванню в просторі тощо.

У розробці практичних завдань щодо використання художньоігрових технологій педагогами було запропоновано: музично-ритмічні ігри, інсценізації, сюжетно-рольові ігри, рухливі ігри - використовувати на уроках фрізичного виховання та прогулянки під час естафет, хороводів українські народні забавки (наприклад, деркачі і калатала). 
Проблемно-евристичні художньо-педагогічні технології спрямовані на творчий розвиток учнів та сприяють фрормуванню, окрім предметних образотворчих компетентностей, ще й ключові, а саме - інформаційнокомунікативні та самоосвітні (навчання впродовж життя). Освітній процес, який здійснюється при використанні проблемно-евристичної технології активізує пізнавальну діяльність учнів та сприяє формуванню їх самостійності.

Під час обговорення цієї технології на груповій дискусії дійшли висновку, що вона вимагає від педагога:

- ретельної підготовки серії взаємопов'язаних запитань, що дозволяє учням самостійно знайти відповідь на проблемне питання;

- емоційності в роботі для підвищення в учнів інтелектуальної активності та зацікавленості в роботі;

- готовності учнів до впровадження технології, що передбачає використання окремих ії елементів, починаючи з першого класу, 3 поступовим ускладненням завдань.

Під час розробки кейсів були запропоновані такі варіанти практичних завдань:

- знайти навмисно допущені педагогом помилки в технологічних картках “Що зайве?”, “Знайди помилку”;

- підібрати технологічну картку, яка найбільше відповідатиме виготовленню зразка народної іграшки;

іграшки;

- розробити самостійно планування виготовлення народної

Музейні технології спрямовані на формування образотворчої компетентності не лише в межах закладу освіти, але й поза ним, що стимулює художню самоосвіту та самовиховання учнів. Педагогам було запропоновано переглянути відеофільми про виставки та музейні експозиції українських народних іграшок. На обговорення виносилася пропозиція створення експозиції шкільного музею "Українська народна іграшка" як осередку освітнього середовища, яку підтримали всі педагоги. Після чого на етапі розробки практичних завдань учасникам тренінгу було запропоновано спроектувати зміст експозиції (різновиди об'єктів, їх опис, розташування, визначення необхідності і фрорми довідкової інформації тощо). Формувати колекцію українських народних іграшок вирішили спільно з учнями та їх батьками шляхом організації самостійної пошукової діяльності.

Під час міні-лекції педагогів ознайомили 3 компетентнісноорієнтованим підходом щодо оцінювання результатів загальної мистецької освіти.

Дуже важливо, що під час рефлексії на тренінгу педагоги визначили важливість формувального оцінювання, оскільки ця форма сприяє:

- встановленню результатів практичної діяльності та самостійності учня, його співробітництва з іншими; 
- розумінню учнем успіхів у певних видах діяльності; труднощів, які виникають під час практичної діяльності;

- заохоченню до взаємодії з педагогом та іншими учнями тощо.

III етап підвищення фахової компетентності був присвячений серії майстер-класів з виготовлення української традиційної народної іграшки.

Для педагогів було підготовлено 5 майстер-класів з виготовлення українських народних іграшок: ляльки “Кубишка-травниця", вузликової ляльки, солом'яного різдвяного павука, коника 3 ниток, ляльки 3 кукурудзяного листя. На майстер-класі під час презентації повідомлялося: коротка інформація про історію виробу; матеріали, які необхідні для виготовлення іграшки; технологічні операції з детальним коментуванням кожної (послідовність виконання роботи). Після цього педагогам було запропоновано виготовити свій варіант української народної іграшки. За потребою надавалася допомога.

Ураховуючи необхідність удосконалення календарно-тематичного планування для кращого розкриття досліджуваної теми, а також рекомендації МОН України щодо календарного планування, які визначають, що педагоги мають право самостійно переносити теми уроків відповідно до засвоєння учнями навчального матеріалу, встановлювати кількість годин на вивчення окремих тем тощо, методичним об'єднанням вчителів початкових класів було проведене узгодження планування уроків трудового навчання та образотворчого мистецтва, на яких розглядається тема декоративно-прикладного мистецтва, зокрема «Українська народна іграшка».

При узгодженні календарно-тематичного планування педагоги намагалися не дублювати теми, а розглядати їх поетапно залежно від сформованих уявлень про декоративно-прикладне мистецтво та народну іграшку, а також умінь і навичок для самостійного виконання практичних робіт.

Ураховуючи, що шкільні музеї є важливим засобом навчальновиховної роботи, а також формування соціальної та громадянської компетентності, на педагогічній нараді було прийняте рішення створення експозиції шкільного музею "Українська народна іграшка". Для цього була організована спільна дослідницька діяльність батьків і учнів, участь у якій сприяла розвитку пошукових та творчих здібностей учнів, формуванню у них вміння самостійно планувати свою роботу та презентувати її. Педагогами були визначені основні напрямки такої роботи:

- дослідження історії української народної іграшки в Україні;

- збір інформації про використання українських народних іграшок в родині та, по можливості, експонатів родинних народних іграшок; збір інформації та експонатів українських народних іграшок, які виготовлялись у різних регіонах України.

На нашу думку, представлена в дослідженні поетапна експериментальна методика підвищення рівня фрахової компетентності педагогів до використання української народної іграшки в корекційновиховному процесі освітніх закладів для дітей молодшого шкільного віку зі зниженим зором має сприяти актуалізації знань щодо змісту та умов 
формування в цієї категорії учнів компетентностей про використання народної іграшки, діяльність з якою сприяє усуненню вторинних відхилень, що виникли внаслідок порушення зору. Реалізація експериментальної методики також сприятиме систематизації власного досвіду з організації і проведення різних видів діяльності з народною іграшкою.

Висновки. Недостатнє опрацювання в сучасній тифлопедагогіці зазначеної проблеми в теоретичному й методичному планах, об'єктивна потреба відповідної практики в її розв'язанні зумовили необхідність розробки.

Результати проведеного дослідження 3 питань застосування практичними працівниками спеціальної школи для дітей зі зниженим зором народної іграшки в навчально-виховному процесі початкової школи засвідчили, що існує ряд проблем, які чекають на своє вирішення, зокрема чинні навчальні програми не передбачають ознайомлення учнів початкових класів 3 народною іграшкою; педагоги мало обізнані 3 народною іграшкою та методикою ії̈ застосування в корекційно-виховній роботі з дітьми, які мають знижений зір; значна частина тифлопедагогів не знають, що народну іграшку можна використати як корекційний засіб.

Запропонована експериментальна методика, що включала проведення семінарів, майстер-класів та тренінгів, сприяла підвищенню рівня фрахової компетентності педагогів до використання української народної іграшки в роботі з дітьми, які мають знижений зір. Перспективу подальших наукових розвідок вбачаємо в розробці педагогічних основ ознайомлення дітей зі зниженим зором з народною іграшкою 3 метою ефективного її використання в корекційно-виховній роботі.

\section{Література}

1. Андрієнко В.І. Вдосконалення процесу навчання сліпих молодших школярів самообслуговуванню [Текст]: дис... канд. пед. наук: 13.00 .03 / Андрієнко Володимир Іванович; АПН України, Ін-т дефектології. - К., 1994. - 133 с.

2. Выготский Л.С. Проблемы дефектологи / Л.С.Выготский / Сост., авт. вступ. ст. и бибилиогр. Т.М. Лифанова; авт. коммент. М.А.Степанова. - М.: Просвещение, 1995. - 527 с.

3. Гребенюк Т.М. Медико-педагогічна корекція зорового сприймання у дошкільників 3 вадами зору: навч. посібник / Т.М.Гребенюк, І.О.Сасіна, Ю.В.Тімакова. - К.: Вид-во НПУ ім. М.П.Драгоманова, 2005. - 147 с.

4. Дашковська А.В. Вивчення стану використання народної іграшки в корекційно-виховному процесі початкової школи для учнів зі зниженим зором / А.В.Дашковська // Збірник наукових праць Хмельницького інститут соціальних технологій Університету «Україна». - Хмельницький: ХІСТ, 2018. - № 16. - С. 72-75.

5. Земцова М.И. Учителю о детях с нарушениями зрения / М.И.Земцова. М.: Просвещение. 1973. - 159 с.

6. Литвак А.Г. Психология слепых и слабовидящих: учеб. пособие [для студ. высших пед. учеб. заведений] / А.Г.Литвак. - СПб.: КАРО, 2006. - 336 с.

7. Масол Л.М. Художньо-педагогічні технології в основній школі: єдність навчання і виховання: метод. посіб. / Л.М.Масол. - Харків: «Друкарня Мадрид», 2015. $-178 \mathrm{c}$.

8. Моргулис И.С. Теоретические основы коррекционно-воспитательного процесса в младших классах школы слепых: автореф. дис. ... д-ра пед. наук: спец. 
13.00.03 «Специальная педагогика» / И.С.Моргулис. - М., 1984. - 31 с.

9. Свиридюк Т.П. Коррекционно-воспитательная работа со слабовидящими детьми дошкольного возраста / Т.П.Свиридюк. - К., 1981. - 74 с.

10. Синьов В.М. Методологія та теорія досліджень в галузі дефектології / В.М.Синьов // Збірник наукових праць Кам'янець-Подільського національного університету імені Івана Огієнка. Серія: Соціально-педагогічна. - 2010. - Вип. 15. C. 7-9.

11. Синьова Є.П. Особливості розвитку і виховання особистості при глибоких порушеннях зору: монографія / Є.П.Синьова. - Вид-во: Нац. пед. ун-т ім. М.П.Драгоманова. - К., 2012. - 441 с.

12. Тарасун В.В. Філософські засади спеціальної освіти / В.В.Тарасун // Дефектологія. - 2004. - № 3. - С. 2-6.

13. Синьова Є.П. Тифлопедагогіка: підручник / Є.П.Синьова, С.В.Федоренко. - К.: НПУ ім. М.П.Драгоманова, 2009. - 325 с.

14. Федоренко С.В., Синьова Є.П., Федоренко І.В. Вивчення стану сформованості дій самообслуговування в молодших дошкільників зі зниженим зором / С.В.Федоренко, Є.П.Синьова, І.В.Федоренко // Актуальні питання корекційної освіти (педагогічні науки): зб. наук. праць. - Вип. 7. Т. 1. - Кам'янецьПодільський: ПП Медобори, 2016. - С. 371-382.

\section{References}

1.Andriyenko V.I. Vdoskonalennya procesu navchannya slipyh molodshyh shkolyariv samoobslugovuvannyu [Tekst]: dys... kand. ped. nauk: 13.00.03 / Andriyenko Volodymyr Ivanovych; APN Ukrayiny, In-t defektologiyi. - K., 1994. - 133 s.

2.Vygotskyj L.C. Problemy defektology / L.S.Vygotskyj / Sost., avt. vstup. st. y bybylyogr. T.M. Lyfanova; avt. komment. M.A.Stepanova. - M.: Prosveshhenye, 1995. $527 \mathrm{~s}$.

3.Grebenyuk T.M. Medyko-pedagogichna korekciya zorovogo spryjmannya u doshkilnykiv z vadamy zoru: navch. posibnyk / T.M.Grebenyuk, I.O.Sasina, Yu.V.Timakova. - K.: Vyd-vo NPU im. M.P.Dragomanova, 2005. - 147 s.

4.Dashkovska A.V. Vyvchennya stanu vykorystannya narodnoyi igrashky $v$ korekcijno-vyhovnomu procesi pochatkovoyi shkoly dlya uchniv zi znyzhenym zorom / A.V.Dashkovska // Zbirnyk naukovyh pracz Hmelnyczkogo instytut socialnyh texnologij Universytetu «Ukrayina». - Hmelnyckyj: XIST, 2018. - \# 16. - S. 72-75.

5.Zemczova M.Y. Uchytelyu 0 detyah $s$ narushenyyamy zrenyya / M.Y.Zemczova. - M.: Prosveshhenye. 1973. - $159 \mathrm{~s}$.

6. Lytvak A.G. Psyhologyya slepyh y slabovydyashhyh: ucheb. posobye [dlya stud. vysshyh ped. ucheb. zavedenyj] / A.G.Lytvak. - SPb.: KARO, 2006. - 336 s.

7. Masol L.M. Hudozhno-pedagogichni texnologiyi $v$ osnovnij shkoli: yednist navchannya i vyhovannya: metod. posib. / L.M.Masol. - Harkiv: «Drukarnya Madryd», 2015. - $178 \mathrm{~s}$.

8.Morgulys Y.S. Teoretycheskye osnovy korrekcyonno-vospytatelnogo processa $\vee$ mladshyh klassah shkoly slepyh: avtoref. dys. ... d-ra ped. nauk: specz. 13.00.03 «Specyalnaya pedagogyka» / Y.S.Morgulys. - M., 1984. - $31 \mathrm{~s}$.

9.Svyrydyuk T.P. Korrekcyonno-vospytatelnaya rabota so slabovydyashhymy detmy doshkolnogo vozrasta / T.P.Svyrydyuk. - K., 1981. - 74 s.

10. Synov V.M. Metodologiya ta teoriya doslidzhen $\vee$ galuzi defektologiyi / V.M.Synov // Zbirnyk naukovyh pracz Kam'yanecz-Podilskogo nacionalnogo universytetu imeni Ivana Ogiyenka. Seriya: Socialno-pedagogichna. - 2010. - Vyp. 15. - S. 7-9. 
11. Synova Ye.P. Osoblyvosti rozvytku i vyhovannya osobystosti pry glybokyh porushennyah zoru: monografiya / Ye.P.Synova. - Vyd-vo: Nacz. ped. un-t im. M.P.Dragomanova. - K., 2012. - 441 c.

12. Tarasun V.V. Filosofski zasady specialnoyi osvity / V.V.Tarasun // Defektologiya. - 2004. - \# 3. - S. 2-6.

13. Synova Ye.P. Tyflopedagogika: pidruchnyk / Ye.P.Synova, S.V.Fedorenko. - K.: NPU im. M.P.Dragomanova, 2009. - 325 c.

14. Fedorenko S.V., Synova Ye.P., Fedorenko I.V. Vyvchennya stanu sformovanosti dij samoobslugovuvannya $v$ molodshyh doshkilnykiv zi znyzhenym zorom / S.V.Fedorenko, Ye.P.Synova, I.V.Fedorenko // Aktualni pytannya korekcijnoyi osvity (pedagogichni nauky): zb. nauk. pracz. - Vy’ p. 7. T. 1. - Kam'yanecz-Podilskyj: PP Medobory, 2016. - S. 371-382.

\section{АНОТАЦІЯ}

У статті відзначається, що корекційно-компенсаторна спрямованість навчання й виховання дітей з порушеннями зору $є$ змістом усієї освітньої діяльності закладу спеціальної освіти, що реалізується під час фрормування компетентностей, потрібних для подальщої їх соціалізації. Важливого значення набуває використання в корекційно-виховній роботі закладів спеціальної освіти для дітей зі зниженим зором молодшого шкільного віку української народної іграшки, діяльність з якою сприяє усуненню вторинних відхилень, що виникли внаслідок порушення зору.

Зазначено, що низький рівень діяльності учнів молодшого шкільного віку зі зниженим зором з народною іграшкою пояснюється тим, що вона не знайшла свого належного місця в освітньому процесі спеціальної школи та характеризується цілим рядом причин, основною з яких $\epsilon$ необізнаність педагогів щодо можливостей ї̈ використання.

Запропонована експериментальна методика підвищення рівня фрахової компетентності педагогів до використання української народної іграшки в корекційно-виховному процесі освітніх закладів для дітей молодшого шкільного віку зі зниженим зором.

Експериментальна методика реалізувалася в три етапи. На першому етапі педагоги на семінарах теоретично ознайомлювались з українською народною іграшкою як видом декоративно-прикладного мистецтва. На другому етапі були проведені тренінги, на яких педагогів знайомили з передумовами розвитку творчої діяльності та технологіями художньо-педагогічної діяльності. Третій етап підвищення фрахової компетентності педагогів був присвячений серії майстер-класів з виготовлення української традиційної народної іграшки. Запропонована експериментальна методика що включала проведення семінарів, майстер-класів та тренінгів, сприяла підвищенню рівня фрахової компетентності педагогів до використання української народної іграшки в роботі з дітьми, які мають знижений зір.

Ключові слова: методика, народна іграшка, компетенція, корекційноосвітній процес, знижений зір. 